Article

\title{
A Comparative Study between Government Support and Energy Efficiency in Malaysian Transport
}

\author{
Saeed Solaymani ${ }^{1, * \mathbb{C}}$ and Saeed Sharafi ${ }^{2}$ \\ 1 Department of Economics, Faculty of Administration and Economics, Arak University, Arak 38156879, Iran \\ 2 Department of Environmental Science, Faculty of Agriculture and Natural Resource, Arak University, \\ Arak 38156879, Iran; sd_solimani@yahoo.com \\ * Correspondence: saeedsolaymani@gmail.com; Tel.: +98-86-3262-1000
}

Citation: Solaymani, S.; Sharafi, S. A Comparative Study between

Government Support and Energy Efficiency in Malaysian Transport. Sustainability 2021, 13, 6196. https:// doi.org/10.3390/su13116196

Academic Editors: Ling Yun He, Xi Lin and Li Liu

Received: 25 March 2021

Accepted: 26 May 2021

Published: 31 May 2021

Publisher's Note: MDPI stays neutral with regard to jurisdictional claims in published maps and institutional affiliations.

\begin{abstract}
The 2030 Agenda states that sustainable transport systems, as well as other associated energy systems and policies, would create a strong economic foundation for all countries. In this regard, countries need to pay more attention to their transport systems. This has been accomplished through a great deal of work and policies that they can enact, such as improving fuel efficiency and government support. Therefore, this study attempts to compare the impact of a $10 \%$ increase in government subsidies and a 5\% increase in improvement in fuel efficiency to the transport subsectors in Malaysia using a computable general equilibrium model (CGE). Results suggest that fuel efficiency improvement is an effective policy in increasing economic growth, exports, investment, and household consumption for the entire economy. While both policies increase output, employment, investment, and household use across the transport subsectors, except water transport, the magnitude of the impacts is greater for improving fuel efficiency policy. Improving fuel efficiency, despite the reduction in energy consumption in the land and water transportation subsectors, has led to a rebound in the air and other transport subsectors. However, increasing government subsidies to transport subsectors increases energy consumption and $\mathrm{CO}_{2}$ emissions in these subsectors. The outcomes of this policy can be used for the future of sustainable development in Malaysian transportation systems.
\end{abstract}

Keywords: improvement in fuel efficiency; government supports; transport subsectors; $\mathrm{CO}_{2}$ emissions; energy consumption

\section{Introduction}

Transport is one of the necessary resources for economic development. The development of transport as a whole, and land transport, in particular, has been taken into significant consideration by all countries. Transport as a whole uses various kinds of energy substantially as it is the main contributor to energy consumption in the majority of countries [1], while industry and households are also important contributors. Therefore, it is one of the top, particularly second top, $\mathrm{CO}_{2}$ emitters in developed and developing economies [2]. This sector has been considered by governments through a variety of supports to facilitate people's access to affordable and modern and diverse transportation services. Governments also provide incentives to stimulate more investment by private investors. Recently, the United Nations Economic Commission for Europe (UNECE) has committed to a specific sustainable development goal for the European transport sector [3]. The 2030 Agenda states that sustainable transport systems, together with universal access to affordable, sustainable, and modern energies, quality and resilient infrastructure, and other policies that increase productive capacities, would build strong economic foundations for all countries. Therefore, countries, to achieve this goal, need to implement suitable and effective policies in their transportation and energy system. One of these policies is increases in government subsidies to the transport sector, such as an increase in infrastructure investment. This policy is necessary for the sustainable economic growth of countries. Transport infrastructure increases the number and the 
quality of goods and services delivered to the customers and leads to economic growth [4]. Another policy is energy efficiency, which can be achieved by the combination of organizational, technical, and operational measures $[5,6]$. It is able to maintain sustainable energy in transport and improve economic growth. Improving energy efficiency in the transport sector provides welfare gain [7]. This leads to sustainable economic and financial development by implementation of suitable policies [8]. Improving energy efficiency by eliminating energy subsidies leads to economic growth [9]. Transport structure and management parameters contribute significantly to the energy efficiency of transport [10].

Malaysia is a developing country with an average economic growth rate of $5 \%$; during the last decade, it has attempted to become an industrialized country. The transport sector was responsible for $4 \%$ of the country's real gross domestic products (GDP) and labor employment of 10\% in 2018 [11]. Under such contributions, this sector is the largest energy consumer and second-largest contributor to total $\mathrm{CO}_{2}$ emissions in Malaysia. It consumed over $36 \%$ of the total final energy demand in 2018 [11] and produced 60 million tons of $\mathrm{CO}_{2}$ emissions in 2017 [12]. The trends in energy consumption, energy efficiency, and energy intensity in Malaysian transportation are presented in Figure 1. It shows that while the energy efficiency trend was increasing (during 2010-2011), and thereafter was decreasing until 2014, the country has experienced increases in energy efficiency after 2014. This reveals that the production of one unit of GDP in the transport sector requires an increasing amount of energy. This result can also be found from the trends of energy use and energy intensity in Figure 1.

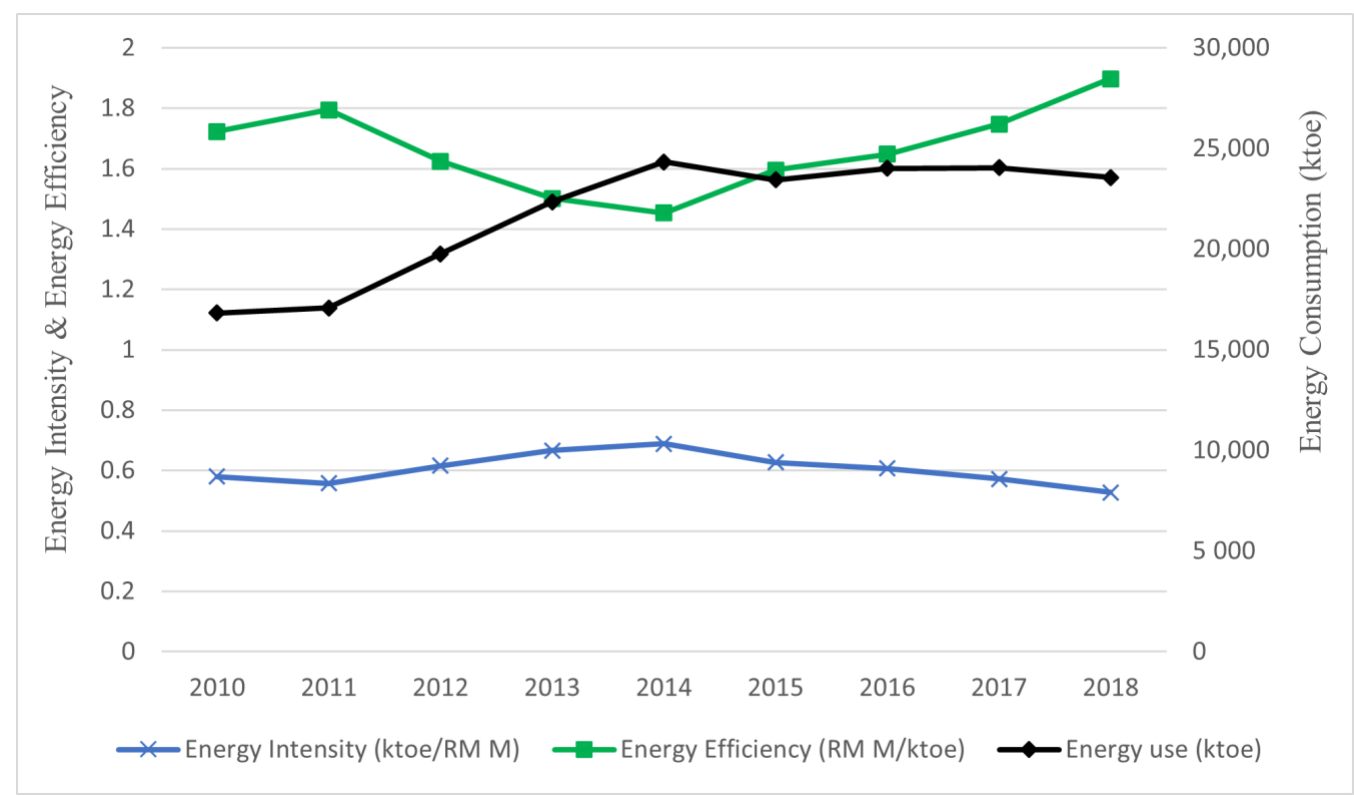

Figure 1. Trends in energy use, energy intensity, and efficiency in the transport sector. Source: author calculation based on Malaysia's Energy Information Hub [13].

Malaysia has a high density of car passengers, which has been influenced by external and internal shocks, such as changes in global oil prices and the removal of energy subsidies. High global oil prices and the removal of energy subsidies reduce energy consumption and $\mathrm{CO}_{2}$ emissions in the country's transport sector [14,15]. These policies and shocks reallocate resources in the economy and affect travel behavior in Malaysia [16]. For example, climate change policies, such as energy and carbon taxes, reduce the use of private cars because of the increase in fuel prices. However, the development of public transportation increases the access of low-income households to affordable and sustainable transport, which in turn improves their welfare level [17].

Accordingly, this study aims at investigating the impacts of improving fuel efficiency by $5 \%$ and the $10 \%$ increase in government subsidies to the transportation sector in Malaysia 
using a computable general equilibrium (CGE) model adapted from [9]. The contribution of this study is analyzing the impacts of energy efficiency improvement and increases in government subsidies on four main transport subsectors that have not been used in previous studies. Furthermore, despite previous studies, it examines the impacts of these policies on key economic, environmental, and energy indicators in the transport subsectors. It also compares the two policies to identify their effect on the whole economy and particularly on the transport sector.

The next section reviews the international and local literature on different policies concerning the transport sector. Section 3 provides the methodology and data. Section 4 presents an analysis and discussion of the results of the study. Section 5 concludes the study and provides some policy suggestions.

\section{Literature Review}

The transport sector, due to its high energy consumption, particularly heavy dependence on oil products and therefore high emissions, is attracting increasing attention in the context of climate change and sustainable development. Accordingly, researchers suggest that to use efficient technologies in the transport sector and motivate private investors, the government needs to provide some incentives and subsidies to this sector [18]. Lenz et al. [19] showed that investment in land transport infrastructure increases economic growth while such investment in rail transport does not positively affect economic growth in EU countries. Public capital may also lead to some economic improvement [20]. The improvement of transport opens up markets and increases interactions between and within sectors and households and organizations and therefore influences economic performance [21]. Although access to transport infrastructure in China does not affect per capita economic growth [22], transport infrastructure contributes to regional economic growth [23]. Transport infrastructure positively affects economic growth in the long run [24]. However, this sector is not benefiting from the elimination of energy subsidies [15] and gains from high global oil prices in Malaysia as a net oil exporter [14]. Sun et al. [25] believe that investments in urban traffic infrastructure reduce air quality in the long run. Pupavac et al. [26] found that the marine subsidy improves sea transport activities. Subsidies are also more sustainable if they are implemented within a context where the regulatory authority has full control over the network, and operations are institutionally separated from regulations [27]. Hu et al. [28] showed that the transport sector gains from the government's purchase subsidy policy, travel limitation policy, production subsidies, and infrastructure policies. Transport infrastructure investments have significant direct and indirect impacts on economic efficiency and economic growth [4]. Saidi et al. [29] argued that investing in modern infrastructure makes it easier to use more energy-efficient modes and alternative technologies that have a positive impact on the economy by minimizing negative externalities. Innovations that stimulate the use of energy-efficient vehicles decrease $\mathrm{CO}_{2}$ emissions in the US [30].

In terms of energy efficiency, serious attention to energy resource management by transport policymakers is necessary. This can be achieved by increasing the efficiency of conventional energy sources and transferring from fossil fuels to renewable sources in the near future [31]. The productivity in the transport sector is different across transport modes, which is higher for land [32]. Liu and Lin [33] demonstrated that transportation structure and energy prices have a positive impact on energy efficiency in China's provincial transportation. Fuel-efficient land vehicles policy can maintain sustainable energy for land transport [34]. Xie et al. [35] found that increased government support, improved land conditions, and public transport are influential factors in the improvement of China's transport energy efficiency. Hao et al. [36] stated that efforts to improve energy efficiency should be balanced across transportation sectors. Economic development contributes the most to the growth of $\mathrm{CO}_{2}$ emissions in the transport sector, while energy efficiency contributes the most to the reduction of $\mathrm{CO}_{2}$ emissions growth [37]. Implementing energyefficient vehicles enhances national production and distribution [38]. Studies on the impacts 
of climate change policies, such as energy and carbon taxes, on the transport sectors show that these policies decrease the output and investment of these sectors [16].

The above literature shows that the majority of studies have examined the impacts of energy efficiency improvement or the subsidy policy on a specific transport sector, such as land transport. Furthermore, they focused only on the impacts of subsidy policy or energy efficiency improvements on energy consumption, economic growth, or $\mathrm{CO}_{2}$ emissions. However, the current study, by employing a comprehensive model, attempts to investigate the impacts of efficiency improvement in fuels and government subsidies on key economic, energy, and environmental variables of four main transport subsectors, namely land, water, air, and other transport subsectors in Malaysia.

\section{Methodology}

\subsection{Description of Scenarios}

This study considers two scenarios. The first is a 5\% increase in efficiency of fuel in the transport subsectors. It is consistent with the average annual growth rate of improved energy efficiency in the transport sector over the last five years (2014-2018) (see Figure 1). The first scenario is similar to an improved technology that consumes energy more efficiently. The second scenario is a $10 \%$ increase in government subsidies to the transport subsectors. It is similar to an increase in infrastructure investments in the transport subsectors. This scenario is also consistent with the average annual growth rate of government expenditures on the transport sector over the last decade.

\subsection{The Model}

This study uses a computable general equilibrium (CGE) model adopted from Solaymani and Kari [15], which was used in recent studies conducted by Solaymani and Yusma [39] and Li and Solaymani [9]. These types of models are powerful and make it possible to study the impacts of external policies and shocks on the entire economy, in particular, on a specific activity or parameter. However, partial equilibrium models like econometrics cannot study the impacts of a policy on multiple sectors and the user cannot trace the impact of a policy on various sectors and economic variables. Despite econometric models that use time series data, these models use specific data (i.e., social accounting matrix (SAM)) for a given period, which is more reliable and available than time series, which deal with unavailability and uncertainty. Therefore, this study employs a CGE model to investigate the objectives of the study. Some other studies also used CGE models for the transport sector, such as Bröcker and Mercenier [40]. On the other hand, one of the limitations of these models is data which belong to a specific year and not time-series data. Although its data are cross sectional, they may not be available for some developing countries. Another limitation of the model is the value of its elasticities and parameters that may not be available for every economic sector and section of an economy. Therefore, users refer to the literature for these elasticities and parameters. Many CGE models may not be able to analyze the sustainability impacts together, i.e., economic, environmental, and social impacts. The structure of the CGE model of the current study is presented in Figure 2. This study uses the general algebraic modeling system (GAMS) to conduct the simulation according to the above scenarios. 


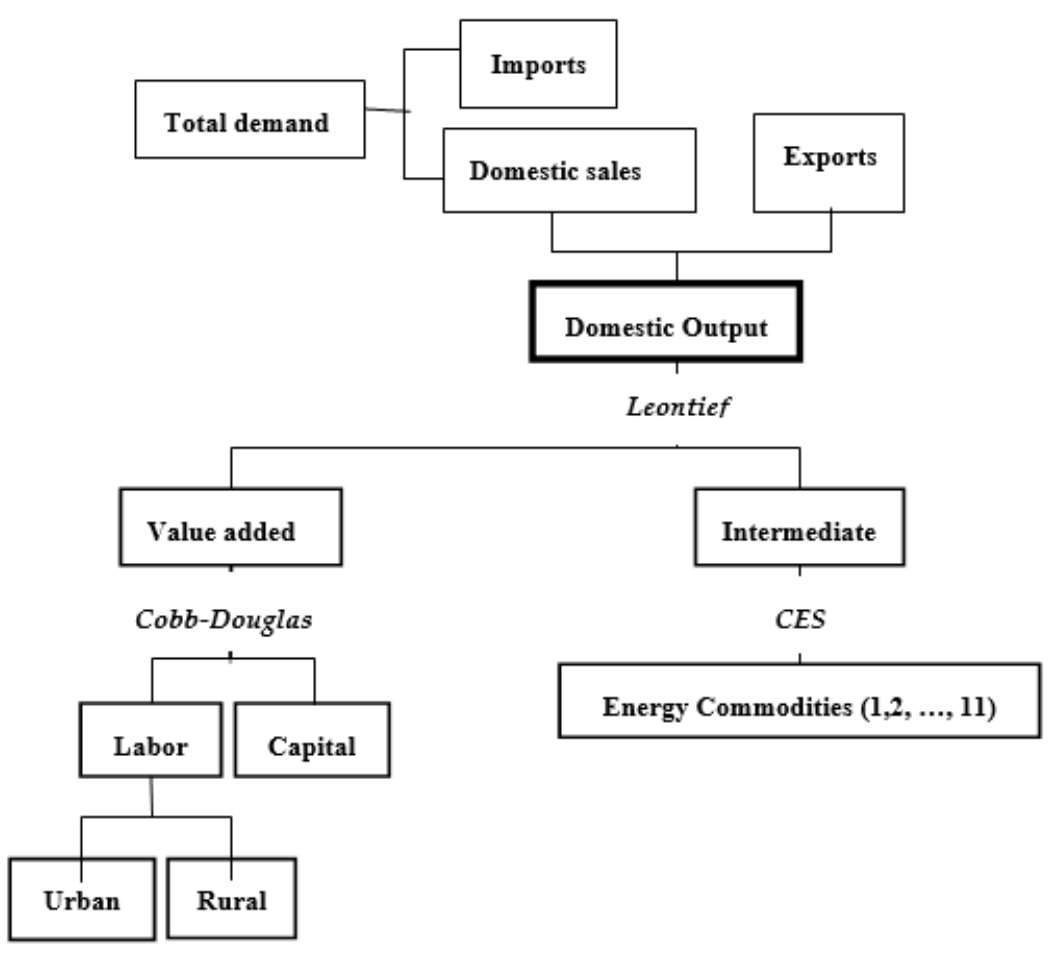

Figure 2. Nested structure of the CGE model.

The structure of the model is as follows. The production function is a Cobb-Douglas function of primary inputs (labor and capital) that provides the outputs of economic activities.

$$
X_{i}=\alpha_{i}^{X} \prod_{f} S C F D_{i, f}^{\beta_{i, f}^{X}}
$$

where $X_{i}$ denotes the output in sector $i ; \alpha_{i}^{X}$ reveals the shift parameter of the production function; $S C F D_{i, f}$ is demand for factor $f$ by sector $i$; and $\beta_{i, f}$ reveals the elasticities in the production function.

$$
W F_{f} \cdot w f \sec _{i, f} \cdot S C F D_{i, f}=X_{i} \cdot P V_{i} \cdot \beta_{i, f}^{X}
$$

where $W F_{i}$ denotes the price of factor $f$; $w f f_{s e c}$, reveals the price of factor $f$ in sector $i$; and $P V_{i}$ is the value-added price.

Energy in sector $j(E N)$ is a constant elasticity of substitution (CES) of all energy commodities in the model.

$$
E N_{j}=\alpha_{j}^{e} \cdot\left[\sum_{e 1} \beta_{e 1, j}^{e} \cdot E N G Y_{e 1, j}^{\rho_{j}^{e}}\right]^{-\frac{1}{\rho_{j}^{e}}}
$$

where $\alpha_{j}^{e}$ denotes the shift parameter of the energy function; $\beta_{e 1, j}^{e}$ is the share parameter of the energy commodity $e 1$ in sector $j$; ENGY $Y_{e 1, j}$ is energy commodities consumption $e 1$ in sector $j ; \rho_{j}^{e}$ reveals the substitution elasticity of the energy function.

Trade has two flows in the model: the flow of domestically produced goods at the international level, called exports $(E)$, and domestic sales $(D)$. This is provided by a constant elasticity of transformation (CET) function.

$$
X_{i e}=\alpha_{i e}^{t} \cdot\left[\beta_{i e}^{t} \cdot E_{i e}^{\rho_{i e}^{t}}+\left(1-\beta_{i e}^{t}\right) \cdot D_{i e}^{\rho_{i e}^{t}}\right]^{-\frac{1}{\rho_{i e}^{t}}}
$$


Another, which is provided as a constant elasticity of substitution (CES), is the flow of internationally produced goods to the local market, called imports $(M)$, and domestic sales.

$$
Q_{i m}=\alpha_{i m}^{c} \cdot\left[\beta_{i m}^{c} \cdot M_{i m}^{-\rho_{i m}^{t}}+\left(1-\beta_{i m}^{c}\right) \cdot D_{i m}^{-\rho_{i m}^{c}}\right]^{-\frac{1}{\rho_{i m}^{c}}}
$$

Household consumption (HCON) is a function of the marginal propensity to saving (mps), household income $(Y H)$, and their income taxes $\left(\tau_{h}\right)$, in which household income is a function of income from primary factors of production $(Y F)$, government transfers (GTRN), transfers from enterprises (YINTP), and factors' income from abroad (FACTIN).

$$
\begin{aligned}
& \operatorname{HCON}_{h}=\sum_{i}\left[h \operatorname{secin}_{i, h} \cdot Y H_{h} \cdot\left(1-m p s_{h}\right) \cdot\left(1-\tau_{h}\right)\right] \\
& Y H_{h}=\sum_{f} h \operatorname{disin}_{h, f} \cdot Y F_{f}+\operatorname{etrn}_{h} \cdot Y I N T P \cdot(1-e t a x) \cdot(1-e s a v)+\operatorname{gtrn}_{h} \cdot G T R N+\text { FACTIN } \cdot \operatorname{sfin}_{h} \cdot E X R
\end{aligned}
$$

where $h \operatorname{secin}_{i, h}$ refers to the proportion of household income in sector $i$; $h$ disin ${ }_{h, f}$ represents the proportion of the household income $h$ of factor $f ; g t r n_{h}$ is the portion of government transfers to households $h$; and $\sin _{h}$ refers to the share of the household $h$ in the income factors from abroad. etax, etrn, and esav are the enterprises' tax rate, the rate of transfer from enterprises to the household, and the saving rate of enterprises, respectively.

The factor income is a function of factor price (their wage rates-WF) and their demand in different economic activities (SCFD). Enterprises' income (YINTP) is the sum of all incomes that it receives from capital (capsh. $\left.Y F_{k}\right)$ and interest rate (INTERS $\left.{ }^{I N T P}\right)$ minus remittances (REMIT) (Equation (9)).

$$
\begin{gathered}
Y F_{f}=\sum_{i} W F_{f} \cdot w f \sec _{i, f} \cdot S C F D_{i, f} \\
Y I N T P=\operatorname{capsh} \cdot Y F_{k}-E X R \cdot R E M I T+I N T E R S^{I N T P}
\end{gathered}
$$

On the government side, the government receives its revenue (GR) from tariffs (TARIFF), the export taxes (EXPTAX), household taxes (HTAX), indirect taxes (ENTAX), and enterprises' taxes (INTPTAX) (Equation (10)). On the other hand, its demand (GD) is a function of government consumption (GCON) (Equation (11)).

$$
\begin{gathered}
G R=\text { TSRIFF }+ \text { INTAX }+ \text { HTAX }+ \text { EXPTAX }+ \text { INPTAX } \\
G D_{i}=\text { govs }_{i} \cdot G C O N
\end{gathered}
$$

Tariff is a function of tariff rates $(t m)$, imports $(M)$, price of imports (pwm), and exchange rate (EXR) (Equation (12)). Similarly, export tax is a function of export tax rate $(t e)$, exports $(E)$, price of export (pwe), and exchange rate (EXR) (Equation (13)). Indirect tax (INTAX) is a function of tax rate on sectoral output (tx) (Equation (14)). The household and enterprises' income taxes are the rates of taxes on the incomes of these agents (Equations (14) and (15)).

$$
\begin{gathered}
\text { TARIFF }=\sum_{i} p w m_{i} \cdot M_{i} \cdot t m_{i} \cdot E X R \\
\text { EXPTAX }=\sum_{i e} p w e_{i e} \cdot E_{i e} \cdot\left(1-t e_{i e}\right) \cdot E X R \\
\text { INTAX }=\sum_{i} P X_{i} \cdot X_{i} \cdot t x_{i} \\
\text { HTAX }=\sum_{h} Y H_{h} \cdot \tau_{h} \\
\text { ENTPTAX }=i t a x \cdot Y I N P
\end{gathered}
$$


In the saving-investment section, households (HSAV) and enterprises (INTSAV) save their income after tax deduction with the rate of mps and isav, respectively (Equations (17) and (18)). Government savings include government revenue (GR) minus government expenditures, including government demand for commodities $(G D)$, the interest rate paid to the world (INTERS $\left.S^{\text {world }}\right)$ and enterprises (INTERS $\left.{ }^{E N T P}\right)$, government transfers (GTRN), and total subsidies (TSUB) (Equation (19)).

$$
\begin{gathered}
H S A V=\sum_{h} Y H_{h} \cdot\left(1-t h_{h}\right) \cdot m p s_{h} \\
I N T S A V=Y I N T P \cdot(1-i t a x) \cdot i s a v \\
G S A V=G R-\sum_{i} P Q_{i} \cdot G D_{i}-E X R \cdot I N T E S R S^{\text {world }}-I N T E R S^{E N T P}-G T R N
\end{gathered}
$$

Therefore, total saving (SAVING) includes all sources of saving, including household saving, government saving, enterprises saving and current account (CURAC) (Equation (20)).

$$
S A V I N G=H S A V+G S A V+I N T P S A V-C U R A C \cdot E X R
$$

Inventory investment (STC) is a share of sectoral output (Equation (21)) and when this is deducted from total investment (INVEST) the fixed investment will be obtained (FINVEST) (Equation (22)).

$$
\begin{gathered}
S T C_{i}=\operatorname{inv}_{i} \cdot X_{i} \\
\text { FINVEST }=I N V E S T-\sum_{i} P Q_{i} \cdot S T K_{i}
\end{gathered}
$$

The volume of investment $(D C)$ can be defined as the ratio of fixed investment to total capital (Equation (23)) and, finally, final demand for productive investment (ID) is obtained from total capital times the volume of investment (Equation (24))

$$
\begin{aligned}
D C_{i} & =\frac{z z_{i} \cdot \text { FINVEST }}{\sum_{j} \text { ccmat }_{j, i} \cdot D C_{j}} \\
I D_{i} & =\sum_{j} c_{j} \cot _{i, j} \cdot D C_{j}
\end{aligned}
$$

Nominal gross domestic product (NGDP) is a combination of value-added $(V)$, indirect (INDTAX), and export taxes (EXPTAX), and total subsidies (Tsub) (Equation (25)), which is a function of sectoral subsidy (Sub) (Equation (26)). However, real GDP is a combination of private $(C D)$ and government $(G D)$ expenditures, enterprises investment expenditure $(I D+S T C)$, and net exports expenditure $(E-M)$ (Equation (27))

$$
\begin{gathered}
N G D P=\sum_{i} P V_{i} \cdot V_{i}+I N T A X+\text { TARIFF }+ \text { EXPTAX }- \text { Tsub } \\
\text { Tsub }=\sum_{i} s u b_{i} \\
R G D P=\sum_{i}\left(C D_{i}+G D_{i}+I D_{i}+S T C_{i}+\sum_{i e} E_{i e}-\sum_{i m}\left(1-\text { tmreal }_{i m}\right) \cdot M_{i m}\right)
\end{gathered}
$$

In the equilibrium section, all expenditures, including private, government, and enterprises expenditure, plus intermediates, must be equal to total composite commodities (Q) (Equation (28)) and total factor demand (SCFD) is equal to total factor supply (FS) (Equation (29)). Furthermore, the current account (CURAC) must equal the total sum of exports and imports (Equation (30)). Finally, total investment is equal to total saving (Equation (31)).

$$
\begin{gathered}
Q_{i}=I N T M_{i}+C D_{i}+G D_{i}+I D_{i}+S T K_{i} \\
\sum_{i} S C F D_{i, f}=F S_{f}
\end{gathered}
$$




$$
\begin{gathered}
\text { CURAC }=\sum_{i m} p w m_{i m} \cdot M_{i m} \cdot t m_{i} \cdot E X R+\sum_{i e} p w e_{i e} \cdot\left(1-t e_{i e}\right) \cdot E_{i e} \cdot E X R \\
\text { AVING }=\text { INVEST }
\end{gathered}
$$

In the price section, there are the following equations. Price of composite commodities $(P Q)$ (Equation (32)), the average output prices $\left(P X_{i}\right)$ (Equation (33)), value-added prices $\left(P V_{i}\right)$ in Equation (34), import price (PM) (Equation (35)), export prices (PE) (Equation (36)), price of capital (PK) (Equation (37)), the price index (PRICIND)) in Equation (38), in which wcpi is the weights of the composite price index, and energy price $(P E N)$, in which $i o_{e 1 p, j}$ denotes intermediate energy commodities (e1p) in sector $j$ (Equation (39)).

$$
\begin{gathered}
P Q_{i}=\left(P D_{i} \cdot D_{i}+P M_{i} \cdot M_{i}\right) / Q_{i} \\
P X_{i}=\left(P D_{i} \cdot D_{i}+P E_{i} \cdot E_{i}\right) / X_{i} \\
P V_{i}=P X_{i} \cdot X_{i} \cdot\left(1-\left(t x_{i}-s u b_{i}\right)\right)-\sum_{j} i o_{i, j} \cdot X_{i} \cdot P Q_{i} \\
P M_{i m}=p w m_{i m} \cdot E X R \cdot\left(1+t m_{i m}\right) \\
P E_{i e}=P W E_{i e} \cdot\left(1-t e_{i e}\right) \cdot E X R \\
P K_{i}=\sum_{j} c c m a t_{j, i} \cdot P Q_{j} \\
P R I C I N D=\sum_{i} w c p i_{i} \cdot P Q_{i} \\
P E N_{j}=\frac{\sum_{e 1}\left(I O_{e 1 p, j} \cdot j+s u b_{j}\right) P Q_{j}}{E N_{j}}
\end{gathered}
$$

\subsection{Data and Macro Closures}

This study uses a social accounting matrix (SAM) that is built using the 2015 inputoutput table and other socioeconomic data from the department of statistics of Malaysia. Table 1 summarizes the SAM. The input-output table contains 124 activities, which for the current study they have aggregated into 32 activities, including Agriculture, Crude Oil and Natural Gas, Coal, Mining and Natural Resources, Food and Tobacco Products, Textiles and Footwear, Wood and Paper Products, Motor Petrol, Diesel, Fuel Oil, LPG, Other Petroleum, Plastic and Chemical Products, Cement and Ceramic Products, Iron and Steel Products, Industrial Machinery, Electrical Machinery, Transport Equipment, Fossil Fuel Electricity,

\begin{tabular}{|c|c|c|c|c|c|c|c|c|c|}
\hline & Commodities & Activities & Factors & Households & Enterprises/Corporations & Government & Savings-Investment & Rest of the World & Total \\
\hline Commodities & & 1221.2 & & 556.7 & & 152.1 & 193.7 & 638.7 & 2762.4 \\
\hline Activities & 2762.4 & & & & & & & & 2762.4 \\
\hline Factors & & 1119.6 & & & & & & & 1119.6 \\
\hline Households & & & 412.2 & & 194.1 & 6.3 & & & 612.6 \\
\hline Enterprises/Corporations & & & 707.4 & & & 7.8 & & & 715.2 \\
\hline Government & & 17.5 & & 26.3 & 123 & & & & 166.8 \\
\hline Savings-Investment & & & & 28.3 & 378 & & & -212.6 & 193.7 \\
\hline Rest of the World & & 404.1 & & 1.3 & 20.1 & 0.6 & & & 426.1 \\
\hline Total & 2762.4 & 2762.4 & 1119.6 & 612.6 & 715.2 & 166.8 & 193.7 & 426.1 & \\
\hline
\end{tabular}
Biofuels Electricity, Hydroelectricity, Solar Electricity, Water and Sewerage and Waste, Construction, Wholesale and Retail Trade, Real Estate, Land Transport, Water Transport, Air Transport, Other Transport Services, Financial, and Services.

In the model, current account, remittances, factor income from abroad, government borrowings and interests, government subsidies, government transfers, and consumption are fixed and the supplies of primary factors of production are constant but they move across economic sectors. The latter means that the results of the study can be interpreted as long-run results.

Table 1. Summary of the SAM of the study. 


\section{Results and Discussion}

\subsection{Impacts on Key Macro Variables}

Table 2 reports the effects of efficiency improvement in fuel and an increase in government subsidies to the transport subsectors on key macroeconomic variables. It is obvious that improving fuel efficiency enhances real and nominal gross domestic product (GDP) and investment while an increase in government support to the transport subsectors decreases them initially. From the point of view of economic theory, improving fuel efficiency leads to productivity gains by decreasing maintenance production costs since overall prices in the economy are decreased, which in turn stimulates production in the economy. This is consistent with the results of Figus et al. [41], who argued that an increase in household energy efficiency increases economic growth. Both policies reduce inflation, which in turn increases household consumption. Therefore, fuel efficiency policy and the increase in transport subsidies increase households' welfare by $0.53 \%$ and $0.12 \%$, respectively. They also lead to an increase in the Malaysian exchange rate (an increase in the value of Malaysian Ringgit (MYR)), resulting in a decrease in total exports. Imports are also decreased because of the increase in domestic products. Finally, both policies increase energy demand and therefore the level of $\mathrm{CO}_{2}$ emissions. We can conclude that improving efficiency is a more effective policy and brings more gains for the entire economy, households, and government. However, it creates the rebound effect. This may be due to the country's developmental stage because Malaysia as a developing country is attempting to use more energy if its cost is reduced.

Table 2. Impacts on key macroeconomic variables (\% changes from base value).

\begin{tabular}{cccc}
\hline Variable & Base Values & Fuel Efficiency & Transport Subsidies \\
\cline { 2 - 2 } & RM Million & & \\
\hline Real GDP & 1085.6 & 0.103 & -0.005 \\
Nominal GDP & 1145.7 & 0.497 & -0.004 \\
Investment & 193.7 & 0.906 & -0.021 \\
Inflation & 1.00 & -0.046 & -0.001 \\
Government Savings & 22.1 & 4.011 & -0.179 \\
Household & 556.7 & 0.164 & 0.001 \\
Consumption & 1761 & 0.534 & 0.124 \\
Welfare & 638.7 & -1.080 & -0.006 \\
Exports & 404.1 & -1.422 & -0.009 \\
Imports & 216.9 & 0.354 & 0.047 \\
Energy Consumption & 4.81 & 0.242 & 0.001 \\
CO ${ }_{2}$ emission & & & \\
\hline
\end{tabular}

Source: simulation results.

\subsection{Impacts on Key Transport Indicators}

The improving fuel efficiency increases the output and investment in all transport subsectors, except water transport (Table 3). This may occur due to the significant increase in the cost of this policy on the water transport towards the most energy-efficient transport chains, which leads to a decrease in capital demand and hence labor employment. These results are consistent with the results of the study conducted by Konur et al. [42]. Although a technological change in the transport sector is very costly in general, it is far greater for water transport. Output prices in the transport sectors are increased due to increases in exports and domestic sales of these sectors. Sperling and Lutsey [43] pointed out that it is difficult to introduce new fuel-efficient propulsion technologies in the transport sector because of poor coordination between the fuel industry and the automotive industry, the need for substantial initial investments in infrastructure, and the entrenchment of consumer expectations and habits. However, an increase in government subsidies to the transport sector increases output and stimulates investment in all transportation subsectors. These results are consistent with the results of the study conducted by Meerstman and Nazemzadeh [44], which showed that government investment in port infrastructure and 
highways stimulates economic growth in Belgium. It also lowers the output prices of all transport subsectors.

Table 3. Impacts on transport output and investment ( $\%$ change from the base value).

\begin{tabular}{ccccc}
\hline Sector & Base Values & Fuel Efficiency & Transport Subsidies \\
\hline & RM Million & \multicolumn{3}{c}{ Output } \\
Land transport & 24 & 0.305 & 0.045 \\
Water transport & 14.1 & -0.632 & 0.002 \\
Air transport & 19 & 0.339 & 0.024 \\
Other transport & 27.5 & 0.258 & 0.031 \\
\hline RM Million & \multicolumn{2}{c}{ Investment } \\
Land transport & 0.93 & 0.301 & 0.040 \\
Water transport & 0.11 & -0.630 & 0.001 \\
Air transport & 0.15 & 0.333 & 0.022 \\
Other transport & 0.24 & 0.246 & 0.028 \\
\hline & RM & \multicolumn{2}{c}{ Output prices } \\
Land transport & 1.00 & -0.588 & -0.070 \\
Water transport & 1.00 & 0.534 & -0.012 \\
Air transport & 1.00 & 0.008 & -0.038 \\
Other transport & 1.00 & 0.211 & -0.030 \\
\hline
\end{tabular}

Table 4 reports the impacts of the policies on employment and household use in the transport subsectors. Although the output of land transport increased, its employment decreased by $0.11 \%$. It shows that improvement in fuel efficiency substitutes the most advanced technologies with labor and therefore decreases labor demand in land transport. Moreover, the results for water transport indicate that a decrease in output results in a decrease in the use of labor in this sector. Obviously, employment increases in other transport subsectors as their outputs increase. The increase in government subsidies to the transport sector increases the output of all transport subsectors, which in turn increases labor employment. This is consistent with the results of Rokicki and Stepniak [45], which showed that transport infrastructure investments have positive and weak impacts on employment and insignificant impacts on economic growth. The decrease in the output prices of land transport leads to significant increases in household use of this sector. Significant increases in the output prices for water transport have reduced household demand for this sector by $0.08 \%$. While the output prices of air and water transport subsectors increased initially, their demand by households increased because their products and services are identified as necessary services. The impacts of government support also show that household demand for all transport subsectors increases as their output prices decrease.

The impacts of fuel efficiency improvement and the increase in government support on the exports and imports of the transport subsectors are presented in Table 5. Fuel efficiency improvement decreases exports of water transport and increases the exports of other transport subsectors. Exports rose because of the increased output of these sectors. However, the decrease happened because of the decrease in the output of water transport. The reductions in transport imports occurred due to the rise in the value of the Malaysian Ringgit (MYR), which increased the prices of domestically produced goods. If the government provides further support to the transport subsectors, their exports increase because of the increase in their output, while their imports fall because of the increases in the prices of domestically produced commodities in these sectors as the exchange rate increases. 
Table 4. Impacts on employment and household demand for transport services (\% change from the base value).

\begin{tabular}{cccc}
\hline Sector & Base Values & Fuel Efficiency & Transport Subsidies \\
\hline & Million Person & \multicolumn{2}{c}{ Employment } \\
Land transport & 2.03 & -0.106 & 0.698 \\
Water transport & 0.34 & -0.281 & 1.097 \\
Air transport & 0.93 & 0.246 & 0.681 \\
Other transport & 2.52 & 0.318 & 0.693 \\
\hline & RM Million & \multicolumn{2}{c}{ Household demand } \\
Land transport & 4.13 & 1.277 & 0.081 \\
Water transport & 0.31 & -0.075 & 0.020 \\
Air transport & 0.54 & 0.632 & 0.049 \\
Other transport & 8.20 & 0.335 & 0.035 \\
\hline
\end{tabular}

Table 5. Impacts on exports and imports in transport subsectors (\% change from the base value).

\begin{tabular}{cccc}
\hline Sector & Base Values & Fuel Efficiency & Transport Subsidies \\
\hline & RM Million & \multicolumn{2}{c}{ Exports } \\
Land transport & 7.29 & 1.011 & 0.091 \\
Water transport & 6.53 & -0.661 & 0.010 \\
Air transport & 7.61 & 0.654 & 0.050 \\
Other transport & 7.43 & 0.449 & 0.052 \\
\hline RM Million & \multicolumn{2}{c}{ Imports } \\
Land transport & 3.76 & -1.058 & -0.045 \\
Water transport & 0.66 & -0.553 & -0.021 \\
Air transport & 3.17 & -0.420 & -0.038 \\
Other transport & 2.88 & -0.073 & -0.005 \\
\hline
\end{tabular}

Improving fuel efficiency decreases energy demand in the land and water transport subsectors, resulting in lower $\mathrm{CO}_{2}$ emissions (Figure 3). It should be noted that the decline in energy demand and $\mathrm{CO}_{2}$ emissions in water transport occurred mainly due to the decline in its production. However, this policy increases energy consumption in the air and other transport subsectors, which in turn increases $\mathrm{CO}_{2}$ emissions in these sectors. This reflects the existence of the rebound effect in the air and other transport subsectors. This result is consistent with the finding of the study conducted by MartínezMoya et al. [46], which argued that improving energy efficiency at ports decreases $\mathrm{CO}_{2}$ emissions. Blesl et al. [47] also showed that energy efficiency through the use of biofuels and methanol is able to reduce $\mathrm{CO}_{2}$ emissions in the transport sector. On the other hand, an increase in government subsidies to the transport subsectors increases energy use and consequently $\mathrm{CO}_{2}$ emissions in all transport subsectors. This is in line with the results of Danish et al. [48], who stated that investment in transport in Pakistan is not environmentally friendly. Danish and Baloch [49] showed that land infrastructure boosts economic growth and impedes environmental quality. This shows that the energy efficiency policy is more effective in reducing energy consumption and $\mathrm{CO}_{2}$ emissions than the subsidy support. 

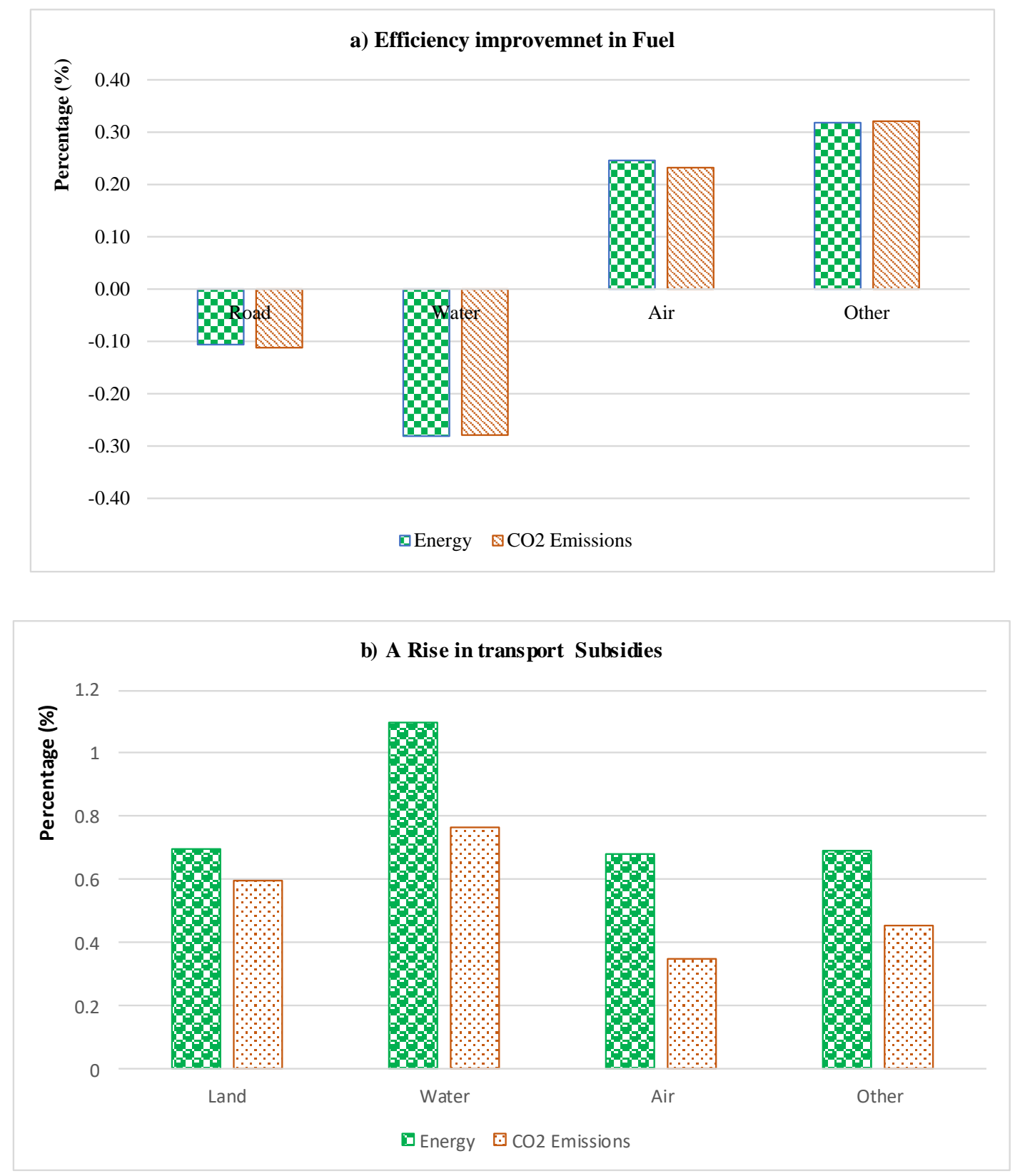

Figure 3. Impacts on energy consumption and $\mathrm{CO}_{2}$ emissions in transport subsectors. Source: simulation results.

\section{Conclusions and Recommendations}

This study investigated the impacts of two policy options on the Malaysian transport subsectors, namely, land, water, air, and other transport services, using a computable general equilibrium (CGE) model. These policies are a $10 \%$ increase in government subsidies, such as infrastructure investment, to the transport sector and the other is an efficiency improvement of $5 \%$ in fuels. The main database of this study is a social accounting matrix that is constructed by the latest Malaysia input-output table for the year 2015 and other socioeconomic data. This study, by examining the impacts of two policies on four major transport subsectors, makes a significant contribution to the existing literature, which concentrates mostly on a specific subsector of transport or a key variable in this sector. This study also explores the impacts of the policies on the majority of important indicators for four transport subsectors that are not provided in partial equilibrium models. The main 
limitation of the study is the cost of the software (GAMS) and the unavailability of an updated SAM as the main database for CGE models.

The above literature showed that the majority of studies have examined the impacts of energy efficiency improvement or subsidy policy on a specific transport sector, such as land transport. Furthermore, they focused only on the impacts of subsidy policy or energy efficiency improvements on energy consumption, economic growth, or $\mathrm{CO}_{2}$ emissions. However, the current study, by employing a comprehensive model attempts to investigate the impacts of efficiency improvement in fuels and government subsidies on key economic, energy, and environmental variables of four main transport subsectors, namely, land, water, air, and other transport subsectors in Malaysia.

In the entire economy, the simulation results suggested that efficiency improvement boosts economic growth and investment while the increase in government subsidies reduces them. These results are consistent with the results of Li and Solaymani [9] for the Malaysian economy. The two policies are beneficial for households as their consumption increases. They also increase overall energy consumption and consequently the level of $\mathrm{CO}_{2}$ emissions in the country. The fuel efficiency improvement by increasing energy consumption manifests the rebound effect throughout the economy, which is consistent with the results of the study conducted by Brockway et al. [50].

On one hand, the improvement of fuel efficiency through the reduction of production costs increases output, investment, and employment in all transport subsectors, except water transport. On the other hand, the subsidy policy through the increase in infrastructure investments increases output, investment, and employment in all transport sectors, but with lower magnitudes than the efficiency policy. Households also gain from both policies as their demand for transport services increases. The policy of efficiency improvement by the use of advanced and low-carbon technologies decreases energy demand and the level of $\mathrm{CO}_{2}$ emissions in the land and water transport subsectors. However, this policy increases energy demand and $\mathrm{CO}_{2}$ emissions in the air and other transport subsectors, demonstrating the existence of the rebound effect in these sectors. This finding is in line with the results of Du et al. [7], who argued that a 10\% increase in energy efficiency manifests a rebound effect of $30 \%$ in the Chinese transport sector. However, the subsidy policy, by increasing investment in all transport subsectors, increases energy demand and $\mathrm{CO}_{2}$ emissions in these sectors. Therefore, efficiency improvement is an effective policy to reduce energy demand and $\mathrm{CO}_{2}$ emissions in the transport sector as a whole. The magnitudes of the impact on output and investment for this policy are greater than those of the subsidy policy.

Although the above results have shown the importance and efficiency of improving fuel efficiency in the transport subsectors, infrastructure investments are a necessary step to development and social wellbeing before improving energy efficiency. Therefore, it is recommended that the government, after the primary and necessary investments in the infrastructure of transport subsectors, focuses on investing in technological innovation and the use of advanced technologies in these sectors. The focus of policymakers on water transport is needed to increase investment in water transport infrastructure and the use of new technologies to achieve its development goals. Prior to this, however, this subsector must be considered to be as critical as other modes of transport because the production of personal watercraft and river regulation cannot be considered more environmentally friendly than other modes of transport.

Future studies may focus on more details of the transport subsectors (i.e., various modes of the transport sector, particularly in land transport) if the extension of the main CGE model database (i.e., SAM) is feasible. Another suggestion is to look at the dynamic impacts of such policies on a long horizon using a dynamic computable general equilibrium model. 
Author Contributions: Conceptualization, S.S. (Saeed Solaymani); methodology, S.S. (Saeed Solaymani); software, S.S. (Saeed Solaymani); validation, S.S. (Saeed Solaymani) and S.S. (Saeed Sharafi); formal analysis, S.S. (Saeed Solaymani); investigation, S.S. (Saeed Solaymani); resources, S.S. (Saeed Solaymani); data curation, S.S. (Saeed Solaymani) and S.S. (Saeed Sharafi); writing-original draft preparation, S.S. (Saeed Solaymani); writing-review and editing, S.S. (Saeed Solaymani); visualization, S.S. (Saeed Solaymani); supervision, S.S. (Saeed Solaymani); project administration, S.S. (Saeed Solaymani); funding acquisition, S.S. (Saeed Solaymani). All authors have read and agreed to the published version of the manuscript.

Funding: This research received no external funding.

Institutional Review Board Statement: Not applicable.

Informed Consent Statement: Not applicable.

Data Availability Statement: The study did not report any data.

Conflicts of Interest: The authors declare no conflict of interest.

\section{References}

1. Solaymani, S.; Kardooni, R.; Kari, F.; Yusoff, S.B. Economic and environmental impacts of energy subsidy reform and oil price shock on the Malaysian transport sector. Travel Behav. Soc. 2015, 2, 65-77.

2. Solaymani, S. $\mathrm{CO}_{2}$ emissions patterns in 7 top carbon emitter economies: The case of transport sector. Energy 2019, 168, 989-1001. [CrossRef]

3. UNECE (United Nations Economic Commission for Europe). Sustainable Development Goals and the UN Transport Conventions; UNECE: Geneva, Switzerland, 2019.

4. Skorobogatova, O.; Kuzmina-Merlino, I. Transport Infrastructure Development Performance. In Proceedings of the 16th Conference on Reliability and Statistics in Transportation and Communication, Riga, Latvia, 19-22 October 2016.

5. Elena, K. Energy efficiency of Bulgarian maritime transport. J. Mar. Technol. Environ. 2020, 2, 23-28.

6. Hue, P.H.; Tuyet, N.T.A. Evaluation of energy intensity of transport service sectors in Vietnam. Environ. Sci. Pollut. Res. 2021, 28, 11860-11868. [CrossRef] [PubMed]

7. Du, H.; Chen, Z.; Zhang, Z.; Southworth, S. The rebound effect on energy efficiency improvements in China's transportation sector: A CGE analysis. J. Manag. Sci. Eng. 2020, 5, 249-263. [CrossRef]

8. Ziolo, M.; Jednak, S.; Savic, G.; Kragulj, D. Link between Energy Efficiency and Sustainable Economic and Financial Development in OECD Countries. Energies 2020, 13, 5898. [CrossRef]

9. Li, Z.; Solaymani, S. Effectiveness of energy efficiency improvements in the context of energy subsidy policies. Clean Technol. Environ. Policy 2021. [CrossRef]

10. Cui, Q.; Li, Y. The evaluation of transportation energy efficiency: An application of three-stage virtual frontier DEA. Transp. Res. Part D 2014, 29, 1-11. [CrossRef]

11. Department of Statistics Malaysia. Time Series Data; Department of Statistics Malaysia: PutraJaya, Malaysia, 2021.

12. International Energy Agency-IEA. CO2 Emissions from Fuel Combustion: 2019 Highlights; International Energy Agency-IEA: Paris, France, 2019.

13. Energy Comission. Malaysia' Energy Information Hub: Statistics; Energy Comission: Putrajaya, Malaysia, 2020.

14. Solaymani, S.; Kari, F. Environmental and economic effects of high petroleum prices on transport sector. Energy 2013, 60, 435-441. [CrossRef]

15. Solaymani, S.; Kari, F. Impacts of energy subsidy reform on the Malaysian economy and transportation sector. Energy Policy 2014, 70, 115-125. [CrossRef]

16. Solaymani, S.; Kardooni, R.; Yusoff, S.B.; Kari, F. The impacts of climate change policies on the transportation sector. Energy 2015, 81, 719-728. [CrossRef]

17. Solaymani, S. Which government supports are beneficial for the transportation subsectors. Energy 2021. forthcoming.

18. Agaton, C.B.; Guno, C.S.; Villanueva, R.O.; Villanueva, R.O. Diesel or Electric Jeepney? A Case Study of Transport Investment in the Philippines Using the Real Options Approach. World Electr. Veh. J. 2019, 10, 51. [CrossRef]

19. Lenz, N.V.; Skender, H.P.; Mirković, P.A. The macroeconomic effects of transport infrastructure on economic growth: The case of Central and Eastern, E.U. member states. Econ. Res. Ekon. Istraživanja 2018, 31, 1953-1964. [CrossRef]

20. Romp, W.E.; de Haan, J. Public capital and economic growth: A critical survey. EIB Pap. 2007, 10, 41-70. [CrossRef]

21. Lakshmanan, T.R. The blander economic consequences of transport infrastructure investments. J. Transp. Geogr. 2011, 19, 1-12. [CrossRef]

22. Banerjee, A.; Duflo, E.; Qian, N. On the land: Access to transportation infrastructure and economic growth in China. J. Dev. Econ. 2020, 145, 102442. [CrossRef]

23. Ke, X.; Lin, J.Y.; Fu, C.; Wang, Y. Transport Infrastructure Development and Economic Growth in China: Recent Evidence from Dynamic Panel System-GMM Analysis. Sustainability 2020, 12, 5618. [CrossRef] 
24. Tripathi, S.; Gautam, V. Land Transport Infrastructure and Economic Growth in India. J. Infrastruct. Dev. 2010, 2, 135-151. [CrossRef]

25. Sun, C.; Luo, Y.; Li, J. Urban traffic infrastructure investment and air pollution: Evidence from the 83 cities in China. J. Clean. Prod. 2018, 172, 488-496. [CrossRef]

26. Pupavac, D.; Krpan, L.; Maršanić, R. The Effect of Subsidies on the Offer of Sea Transport. Naše More Znan. Časopis Za More I Pomor. 2017, 64, 54-57.

27. Dawood, G.; Mokonyama, M. Towards a More Optimal Passenger Transport System for South Africa: Design of Public Transport Operating Subsidies. Counc. Sci. Ind. Res. 2015, 62, 192-213.

28. Hu, Y.; Wang, Z.; Li, X. Impact of policies on electric vehicle diffusion: An evolutionary game of small world network analysis. $J$. Clean. Prod. 2020, 265, 121703. [CrossRef]

29. Saidi, S.; Shahbaz, M.; Akhtar, P. The long-run relationships between transport energy consumption, transport infrastructure, and economic growth in MENA countries. Transp. Res. Part A 2018, 111, 78-95. [CrossRef]

30. Raza, S.A.; Shah, N.; Sharif, A. Time frequency relationship between energy consumption, economic growth and environmental degradation in the United States: Evidence from transportation sector. Energy 2019, 173, 706-720. [CrossRef]

31. Manuela, T. Towards sustainable and secure development: Energy efficiency peculiarities in transport sector. J. Secur. Sustain. Issues 2018, 7, 719-726.

32. Melo, P.C.; Graham, D.J.; Brage-Ardao, R. The productivity of transport infrastructure investment: A meta-analysis of empirical evidence. Reg. Sci. Urban Econ. 2013, 43, 695-706. [CrossRef]

33. Liu, W.; Lin, B. Analysis of energy efficiency and its influencing factors in China's transport sector. J. Clean. Prod. 2018, 170, 674-682. [CrossRef]

34. Abdallah, K.B.; Belloumi, M.; Wolf, D.D. International comparisons of energy and environmental efficiency in the land transport sector. Energy 2015, 93, 2087-2101. [CrossRef]

35. Xie, C.; Bai, M.; Wang, X. Accessing provincial energy efficiencies in China's transport sector. Energy Policy 2018, 123, 525-532. [CrossRef]

36. Hao, H.; Liu, Z.; Zhao, F. An overview of energy efficiency standards in China's transport sector. Renew. Sustain. Energy Rev. 2017, 67, 246-256. [CrossRef]

37. Liang, Y.; Niu, D.; Wang, H.; Li, Y. Factors Affecting Transportation Sector $\mathrm{CO}_{2}$ Emissions Growth in China: An LMDI Decomposition Analysis. Sustainability 2017, 9, 1730. [CrossRef]

38. Tromaras, A.; Margaritis, D.; Moschovou, T. Energy Consumption and Perspectives on Alternative Fuels for the Transport Sector: A National Energy Policy for Greece. In Advances in Mobility-as-a-Service Systems; Nathanail, E.G., Adamos, G., Karakikes, I., Eds.; Springer: Berlin/Heidelberg, Germany, 2021; p. 1278. [CrossRef]

39. Solaymani, S.; Yusma, N. Poverty effects of food price escalation and mitigation options: The case of Malaysia. J. Asian Afr. Stud. 2018, 53, 685-702. [CrossRef]

40. Bröcker, J.; Mercenier, J. General equilibrium models for transportation economics. In A Handbook of Transportation Economics; De Palma, R.A., Indsey, E., Quinet, R., Vickerman, H., Eds.; Edward Elgar Publishing: Cheltenham, UK, 2011. [CrossRef]

41. Figus, G.; Lecca, P.; McGregor, P.; Turner, K. Energy efficiency as an instrument of regional development policy? The impact of regional fiscal autonomy. Reg. Stud. 2019, 53, 815-825. [CrossRef]

42. Konur, O.; Bayraktar, M.; Pamik, M.; Kuleyin, B.; Nuran, M. The Energy Efficiency Gap in Turkish Maritime Transportation. Pol. Marit. Res. 2019, 26, 98-106. [CrossRef]

43. Sperling, D.; Lutsey, N. Energy Efficiency in Passenger Transportation. Natl. Acad. Eng. 2014, 44, $22-30$.

44. Meersman, H.; Nazemzadeh, M. The contribution of transport infrastructure to economic activity: The case of Belgium. Case Stud. Transp. Policy 2017, 5, 316-324. [CrossRef]

45. Rokicki, B.; Steppniak, M. Major transport infrastructure investment and regional economic development- An accessibility-based approach. J. Transp. Geogr. 2018, 72, 36-49. [CrossRef]

46. Martínez-Moya, J.; Vazquez-Paja, B.; Maldonado, J.A.G. Energy efficiency and $\mathrm{CO}_{2}$ emissions of port container terminal equipment: Evidence from the Port of Valencia. Energy Policy 2019, 131, 312-319. [CrossRef]

47. Blesl, M.; Das, A.; Fahl, U.; Remme, U. Role of energy efficiency standards in reducing $\mathrm{CO}_{2}$ emissions in Germany: An assessment with TIMES. Energy Policy 2007, 35, 772-785. [CrossRef]

48. Danish; Baloch, M.A.; Suad, S. Modeling the impact of transport energy consumption on $\mathrm{CO}_{2}$ emission in Pakistan: Evidence from ARDL approach. Environ. Sci. Pollut. Res. 2018, 25, 9461-9473. [CrossRef] [PubMed]

49. Danish; Baloch, M.A. Dynamic linkages between land transport energy consumption, economic growth, and environmental quality: Evidence from Pakistan. Environ. Sci. Pollut. Res. 2018, 25, 7541-7552. [CrossRef] [PubMed]

50. Brockway, P.E.; Sorrell, S.; Semieniuk, G.; Heun, M.K.; Court, V. Energy efficiency and economy-wide rebound effects: A review of the evidence and its implications. Renew. Sustain. Energy Rev. 2021, 141, 110781. [CrossRef] 